\title{
VOSTOK, ANTARCTICA, ICE CORE: THE DUST RECORD OVER THE LAST CLIMATIC CYCLE ( 160 ka)
}

\author{
(Abstract) \\ by \\ L. Mounier $*$, J.R. Petit ${ }^{* *}$, J. Jouzel ${ }^{* *}$, C. Lorius ${ }^{*}$, Ye.S. Korotkevich ${ }^{* * *}$ and N.I. Barkov ${ }^{* * *}$ \\ * (Laboratoire de Glaciologie et Géophysique de l'Environnement du C.N.R.S., \\ B.P. 96, 38402 St Martin d'Hères Cédex, France) \\ ** (Laboratoire de Géochimie Isotopique / LODYC, CEA/IRDI/DESICP, \\ DPC-CEN Saclay, 91191 Gif sur Yvette Cédex, France) \\ *** (Arctic and Antarctic Research Institute, Ul. Beringa 38, 199226 Leningrad, U.S.S.R.)
}

\section{ABSTRACT}

The $2083 \mathrm{~m}$ Vostok Antarctic ice core provides a unique opportunity for access to many paleoclimatic and paleo-environmental proxy data. This core, which has been dated by using a glaciological model, fully covers the last glacial-interglacial cycle, and goes back to the ice age which preceded the last interglacial ( 160 ka B.P.).

A continuous deuterium record is now available and we have interpreted it in terms of local temperature changes. This record is dominated by the large $100 \mathrm{ka}$ glacial-interglacial oscillation, with a maximum temperature amplitude of about $11^{\circ} \mathrm{C}$; the long Last Glacial period is very well documented and it is confirmed that the warmest part of the Last Interglacial period was about $2^{\circ} \mathrm{C}$ warmer than the Holocene. Comparison with the ice-volume marine record shows that the Vostok climate record is of relatively large geographical significance, which makes it possible to establish, over the last $160 \mathrm{ka}$, the link between worldwide climatic changes and the Vostok dust record that we present here.

This dust content corresponds to the non-soluble microparticles. It was obtained on a discontinuous basis (1 sample $=$ about $\sim 10 \mathrm{~m}$ ). Due to the very low concentration of some samples (down to $20 \times 10^{-9} \mathrm{~g} \mathrm{~g}^{-1}$ ) and cracks in the ice from the first $1000 \mathrm{~m}$ depth, we used stringent decontamination procedures. Size distribution and total concentration were measured, using a Coulter counter and an optical microscope; the results were tested against chemical measurements (aluminium concentration). In previous studies, it has been shown that the main proportion of insoluble microparticles is of terrigenous origin and represents the small-sized (radius $<2 \mu \mathrm{m}$ ) dust produced on the continents.

The Vostok record displays an increase in dust concentration of up to 20 times during the coldest climatic periods, coupled with the presence of larger particles. It confirms, on a much longer time-scale, a characteristic previously noted in Antarctic and Greenland ice cores over the Last Glacial Maximum. This large increase is attributed to a greater areal extent of global tropical aridity during the cold periods, coupled with higher efficiency of atmospheric circulation in respect of dust production and transport. Beyond this, the relationship between the dust input and the successive stages during the Last Glacial is now very well documented and will be discussed with a view to correlating the Vostok climatic record with other marine and terrestrial paleodata.

\section{A HIGH-RESOLUTION ANION PROFILE OF AN ICE CORE FROM DOLLEMAN ISLAND, ANTARCTIC PENINSULA}

\section{(Abstract)}

by

Robert Mulvaney and David A. Peel

(British Antarctic Survey, Natural Environment Research Council,

High Cross, Madingley Road, Cambridge, CB3 OET, England)

\section{ABSTRACT}

In January 1986, a $133 \mathrm{~m}$ ice core, with an estimated age at the bottom of $300-350$ years, was collected (using an electromechanical drill) on Dolleman Island $\left(70^{\circ} 35.2^{\prime} \mathrm{S}\right.$, $60^{\circ} 55.5^{\prime} \mathrm{W}$; $398 \mathrm{~m}$ a.s.1.; $10 \mathrm{~m}$ temperature $\left.-16.75^{\circ} \mathrm{C}\right)$. The site lies on the east coast of the Antarctic Peninsula and has a continental-type climate dominated by perennial sea ice in the Weddell Sea. The core is being analysed for a range of chemical impurities, in order to assess their potential as indicators of past climate.

High-resolution (10-15 samples $\mathrm{a}^{-1}$ ) continuous profiles of the anionic species $\mathrm{Cl}^{-}, \mathrm{NO}_{3}{ }^{-}$and $\mathrm{SO}_{4}{ }^{2-}$, together with the cation $\mathrm{Na}^{+}$, have been measured on a section of the core from 26 to $71 \mathrm{~m}$ depth. The core has previously been dated between 0 and $32 \mathrm{~m}$ depth using the $\delta^{18} \mathrm{O}$ profile (Peel and others 1988). Lack of $\delta^{18} \mathrm{O}$ data for the section $32-71 \mathrm{~m}$ forced us to seek an alternative method of dating. 